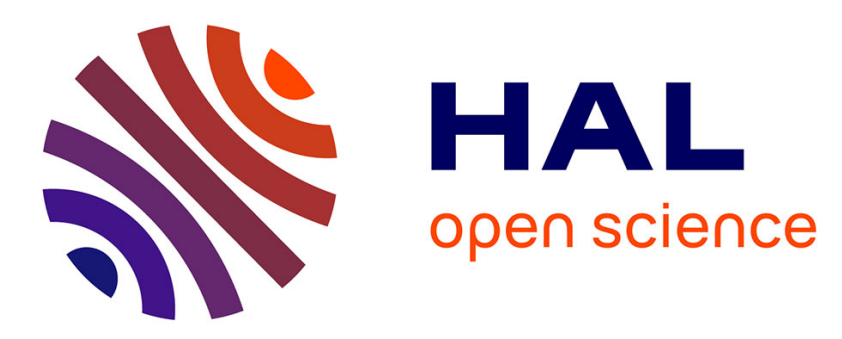

\title{
Explaining perceived ability among older people to provide care as a result of HIV and AIDS in South Africa
}

Hermien Boon, Shamagonam James, Robert A.C. Ruiter, Bart van den Borne, Eka Esu-Williams, Priscilla Reddy

\section{To cite this version:}

Hermien Boon, Shamagonam James, Robert A.C. Ruiter, Bart van den Borne, Eka Esu-Williams, et al.. Explaining perceived ability among older people to provide care as a result of HIV and AIDS in South Africa. AIDS Care, 2010, 22 (04), pp.399-408. 10.1080/09540120903202921 . hal-00590594

\section{HAL Id: hal-00590594 https://hal.science/hal-00590594}

Submitted on 4 May 2011

HAL is a multi-disciplinary open access archive for the deposit and dissemination of scientific research documents, whether they are published or not. The documents may come from teaching and research institutions in France or abroad, or from public or private research centers.
L'archive ouverte pluridisciplinaire HAL, est destinée au dépôt et à la diffusion de documents scientifiques de niveau recherche, publiés ou non, émanant des établissements d'enseignement et de recherche français ou étrangers, des laboratoires publics ou privés. 

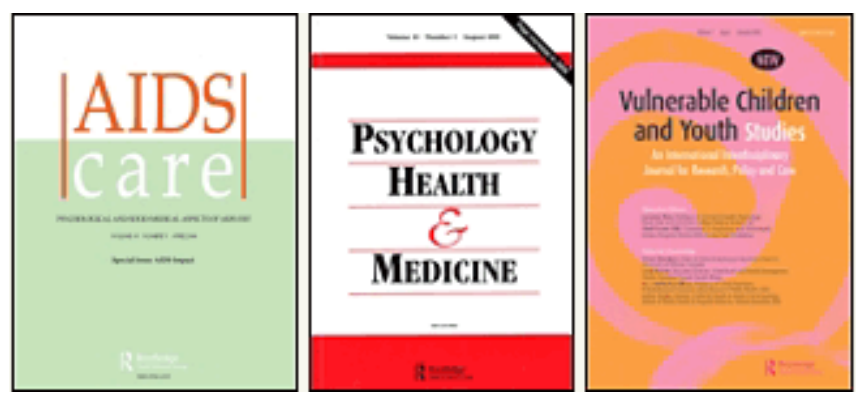

\section{Explaining perceived ability among older people to provide care as a result of HIV and AIDS in South Africa}

\begin{tabular}{|r|l|}
\hline Journal: & $\begin{array}{l}\text { AIDS Care - Psychology, Health \& Medicine - Vulnerable Children } \\
\text { and Youth Studies }\end{array}$ \\
\hline Manuscript ID: & AC-2008-12-0586.R1 \\
\hline Journal Selection: & AIDS Care \\
\hline Keywords: & Older people, Caregiving, South Africa, HIV/AIDS \\
\hline \multicolumn{2}{|l}{} \\
\hline
\end{tabular}

\section{S) ScholarONE" \\ Manuscript Central}


Explaining perceived ability among older people to provide care as a result of HIV and AIDS in South Africa

\begin{abstract}
In South Africa, older people have become the primary caregivers of children and grandchildren infected or affected by HIV and AIDS. This study explores the determinants of the perceived ability to care for children and grandchildren in the domains of providing nursing care, communicating with (grand) children, generating income, and to relax. Structured one-on-one interviews were conducted among 409 isiXhosa speaking older people in two sites in the Eastern Cape Province of South Africa. Results showed that perceived ability among older people to provide nursing care was primarily dependent on the level of knowledge on accessing grants and personal norm towards providing care. Perceived ability to communicate effectively with children and grandchildren was most strongly predicted by a positive attitude towards communication and perceived ability to provide income was influenced by a more negative attitude towards people living with HIV or AIDS. Perceived ability to relax was dependent on more negative attitudes towards communication, lower perceived responsibility to provide income, and a higher perceived behaviour control over providing nursing care. The findings of this study add relevant information to understanding the psychosocial context in which older people provide HIV and AIDS related care and support the development of targeted programmes to assist older people in their role as caregiver.
\end{abstract}

Keywords: Older people, care-giving, South Africa, HIV, AIDS

Abstract word count: 209 / Full word count: 3239 
Explaining perceived ability among older people to provide care as a result of HIV and AIDS in South Africa

In the past few years the HIV and AIDS epidemic has become one of the most important public health challenges in South Africa. A recent report by the Department of Health indicated that 5.4 million South Africans were infected with HIV with the rate of infection being highest amongst people between the ages of 15 and 49 years (Department of Health, 2007). As health services are unable to accommodate the increasing numbers of patients, the care of sick adult children and orphaned grandchildren is primarily left in the hands of elderly parents (Ntozi \& Nakayiwa, 1999; Williams \& Tumwekwase, 2001), mainly elderly women (Madhavan, 2004; Ssengonzi, 2008) who often have little or no support to assume responsibilities for the physical, emotional and economic needs of their dependents (Freeman \& Nkomo, 2006; Knodel, 2005; Ntozi \& Nakayiwa, 1999; Nyambedha, Wandibba, \& AagaarHansen, 2003; Schatz, 2007; Ssengonzi, 2007; Williams \& Tumwekwase, 2001).

In South Africa, the situation of grandparents caring for their adult and grandchildren is however not new. Its history of Apartheid and labour migration systematically divided African families by recruiting men and women to the centres for employment (Chazan, 2008; Madhavan, 2004; Marais, 2005). Families were in a reciprocal exchange while older people facilitated the economic migration of younger adults by caring for their grandchildren and safeguarding the family land and assets (Hosegood \& Timaeus, 2006). What is new to this situation is that AIDS has undermined the traditional reciprocal care arrangements as migrant parents fall ill and die, and therefore can no longer provide remittances to the grandparents caring for their children (Chazan, 2008; Madhavan, 2004; Marais, 2005). Besides, parents 
themselves may move back home to be nursed (Clark, Collinson, Kahn, Drullinger, \& Tollman, 2007; Marais, 2005; Schatz, 2007). As a result, older people have to endure the emotional, physical, financial and social costs that arise from their role as caregivers (e.g., Freeman \& Nkomo, 2006; Ntozi \& Nakayiwa, 1999; Nyambedha, Wandibba, \& Aagaar-Hansen, 2003; Schatz, 2007; Ssengonzi, 2007).

To support older people in their role as caregivers, an understanding of their beliefs and needs with respect to providing care is required. Existing research has identified potential factors related to the care-giving roles of older caregivers (Freeman \& Nkomo, 2006; Ssengonzi, 2007; Ssengonzi, 2008; Williams \& Tumwekwase, 2001), but there is a lack of evidence regarding the relative contributions of these factors in explaining the perceived ability to provide care. This paper therefore aims to identify the psychological correlates of the perceived ability of older caregivers to provide different aspects of care which will impact on the development of targeted programmes to assist older caregivers. Further, the results of this case study in combination with results from other studies adds to a better understanding of the psychosocial context within which older caregivers provide HIV and AIDS related care.

\section{Method}

\section{Study Design}

This quantitative study consisted of a cross-sectional survey among 409 isiXhosa speaking elderly caregivers of 60 years and older, who reported caring for their sick adult children and/or grandchildren as a result of HIV and AIDS. The elderly caregivers were from Motherwell and Uitenhage, two districts in the Eastern Cape of South Africa.

\section{Study Setting}


Historically the Eastern Cape is home to a predominantly isiXhosa speaking population and portrays a culture rich in traditions. The study sites of Motherwell and Uitenhage consist of informal settlements and are part of the Nelson Mandela Metropolitan Municipality that has a population of just over 1 million people (Statistics South Africa, 2007). The majority of the population is African, younger than 30 years of age, do not have a secondary school qualification and live below the Household Subsistence Level poverty line on an annual income of R19200 (about 2313 USD) (Department of Provincial and Local Government South Africa, 2008; Nelson Mandela Bay Municipality, 2008).

As with many informal settlements in the Eastern Cape, Motherwell and Uitenhage are faced with high rates of unemployment, poverty and service delivery backlogs (Nelson Mandela Bay Municipality, 2008) and a high prevalence of HIV infection. In 2006, 29 percent of the antenatal clinic attendees were found to be HIV positive (Department of Health in South Africa, 2007). In the Nelson Mandela Metropolitan HIV and AIDS was most prevalent among the African population. The African population had the largest number of maternal (81.2\%) and paternal (70.3\%) orphans (Development Partners, 2007).

\section{Participants}

In total 200 participants from Uitenhage and 209 from Motherwell completed the survey. Eight participants did not fulfil the inclusion criteria and were removed from the analyses. The inclusion criteria were that participants spoke isiXhosa, were over the age of 60 and were looking after one or more children and/or grandchildren. The age of 60 was maintained as cut-off point as this is the pensionable age for women in South Africa. This resulted in a total sample of 401 elderly caregivers.

\section{Procedure}


As no detailed population statistics were available for the study sample from which a probability sample could be extracted, community health workers were approached to provide access to caregivers with whom they had worked with extensively. The community health workers were employed by Age-in-Action, a local non-governmental organisation and partner in this study.

Eighteen trained community health workers, nine from Motherwell and nine from Uitenhage, all first language isiXhosa speaking women were recruited onto the study. They were responsible for inviting the participants who received services from the Age-in-Action club to participate in the study. Through a snow-ball effect some older persons in the community became aware of the study and showed their interest to participate. They were included if they matched the inclusion criteria.

The community health workers conducted one-on-one interviews with the participants. Questions and response options were read out to the participants and answers were recorded on paper questionnaires. The interviews were conducted in isiXhosa, the first language of both interviewers and participants. Each interview took about one hour and twenty minutes. Interviews took place at the homes of the participants where they usually receive the services provided by the Age-in-Action club. As the health workers were known to the participants and they usually visited them in their homes there was minimal concern that these visits would arouse suspicion or curiosity from neighbours and family.

Detailed information about the content, procedures and confidentiality of the study was provided to the participants both verbally and in writing in isiXhosa before consent was obtained. Ethical approval for the study was granted by the South African Medical Association Ethics Committee.

\section{Measurement Instrument}


The measurement instrument was based on existing literature about older people as providers of care, foregoing qualitative and quantitative research (Boon et al., 2009a; Boon et al., 2009b; Freeman \& Nkomo, 2006; Reddy, 2005; Nyambedha, Wandibba, \& Aagaard-Hansen, 2003; Ssengonzi, 2007; Williams \& Tumwekwase, 2001), and general predictors of human behaviour derived from social cognition models (Connor \& Norman, 2005). Demographic questions concerning age, gender, relationship status, monthly income and number of dependents were included.

All psychological measures were based on Likert-type items with three or five response options. For each measure, scores on items that showed sufficient internal consistency (Cronbach's alpha $[\alpha]>$.60) were averaged into one single index. Higher scores reflect a stronger presence of the concerning variable. Based on previous research (Boon et al., 2009a; Reddy, 2005), four care abilities were identified that served as outcome variables; (1) the perceived ability to provide nursing care; (2) the perceived ability to effectively communicate with children in different generations; (3) the perceived ability to provide an income for the household, and (4) the perceived ability to take time to relax. An overview of the psychological measures, including sample items and the Cronbach's alpha, is presented in Table 1.

[Table 1 about here]

\section{Data analysis}

In the main analyses, bivariate correlations were calculated for the psychosocial variables. As eighteen interviewers were responsible for data collection, all participants were nested within a certain interviewer. To control for possible influences of the interviewer on the individual's responses, linear mixed model analyses were conducted to determine for each of the four dimension of perceived caring ability the unique contribution of significant $(p<.05)$ univariate correlates, 
with interviewer included as random effect variable. Furthermore, to control for possible differences between the two study sites, significant correlate $\mathrm{x}$ site interactions were included in the mixed model analyses. Subsequently simple effect analyses were conducted to determine for each site the influence of the correlate on the specific dimension of perceived ability. A 5\% significance level was observed throughout.

Results

\section{Demographics}

Most of the participants were female $(\mathrm{N}=344 ; 85.8 \%)$, widowed $(\mathrm{N}=211$; $52.6 \%)$ and between 60 and 69 years of age $(\mathrm{N}=184 ; 45.9 \%)$. About half of the participants $(\mathrm{N}=199 ; 49.6 \%)$ went to school, of which 148 (74.4\%) completed only primary school. The majority of older persons $(\mathrm{N}=261 ; 65.1 \%)$ had to manage with a monthly income between 500 and 1000 South African Rand (approx. between 60 and 120 USD at the time of our research). For most participants $(\mathrm{N}=291 ; 72.6 \%)$, the old age government grant of 740 South African Rand per month (approx. 89 USD) was the main source of income.

\section{Care-giving Details}

On average, elders cared for 4.65 children and grandchildren (range 1 - 16). In total, $118(29.4 \%)$ caregivers cared for only grandchildren and $11(2.7 \%)$ provided care for only adult children. The majority of 224 (55.9\%) caregivers cared for both grandchildren and adult children, and $46(11.4 \%)$ caregivers also cared for other dependents, such as grandchildren or adult children of relatives or neighbours. Correlates of perceived abilities related to providing care

Means, standard deviations and inter-correlations of the study measures are shown in Table 2. On the outcome measures, the highest mean score was found for 
the perceived ability to communicate with children and grandchildren, followed by the ability to provide nursing care and the ability to relax. The lowest mean score was found for the older person's perceived ability to provide an income.

[Table 2 about here]

Table 3 displays the estimates of fixed effect $(\beta)$, standard error (SE), and explained variance $\left(\mathrm{R}^{2}\right)$ for each dimension of perceived caring ability.

[Table 3 about here]

Perceived ability to provide nursing care

To explain the variance in providing nursing care, unique contributions were found for knowledge on accessing grants, personal norm towards providing care, attitude towards people living with HIV or AIDS, perceived care burden, and subjective norm towards providing care. Higher scores on these variables were related to more positive perceptions of the ability to provide nursing care. In addition, significant interactions between site of study and personal norm towards providing care, knowledge on accessing grants, and perceived behavioural control over providing nursing care were found respectively. Simple effect analyses showed that among those living in Uitenhage personal norm towards providing care $(\beta=.21 ; \mathrm{SE}=$ $.04 ; \mathrm{p}<.001)$ and knowledge on accessing grants $(\beta=.20 ; \mathrm{SE}=.04 ; \mathrm{p}<.001)$ were positively associated with the ability to provide nursing care, whereas in Motherwell no significant associations were found for both concepts $(\beta=-.14 ; \mathrm{SE}=.08 ; \mathrm{p}>.05$ and $\beta=-.02 ; \mathrm{SE}=.04 ; \mathrm{p}>.05$, respectively). Furthermore, the interaction pattern between site and perceived behaviour control over providing nursing care showed a positive relation to the perceived ability to provide care in Motherwell $(\beta=.17$; SE $=$ $.06 ; \mathrm{p}<.01)$, whereas in Uitenhage no significant relationship was found $(\beta=-.01 ; \mathrm{SE}$ 
$=.06 ; \mathrm{p}>.05)$. The total model explained $41 \%$ of the total variance in perceived ability to provide nursing care.

Perceived ability to communicate effectively with dependents

The perceived ability to communicate with dependents was explained with unique contributions from attitude towards communication, attitude towards people living with HIV or AIDS, perceived behaviour control over providing nursing care, knowledge on accessing grants and subjective norm towards providing care. Higher scores on these variables were associated with higher scores in the outcome variable. Furthermore, the association between knowledge on accessing grants and perceived ability to communicate effectively with dependents differed for Motherwell and Uitenhage. In Uitenhage knowledge on accessing grants was found to be significantly correlated with the ability to communicate effectively with dependents $(\beta=.06$; SE $=$ $.02 ; \mathrm{p}<.01)$, whereas in Motherwell no significant association was found $(\beta=-.02$; $\mathrm{SE}=.02 ; \mathrm{p}>.05)$. The total model explained $49 \%$ of the variance in the perceived ability to effectively communicate with dependents.

\section{Perceived ability to provide income}

A higher perceived ability to provide income was associated with a more negative attitude towards people living with HIV or AIDS, a more positive attitude towards communication, a more positive personal norm towards providing care, a higher knowledge on accessing grants, and a more positive subjective norm towards providing care. Furthermore, interactions with site were found for perceived feelings of helplessness, attitude towards people living with HIV and AIDS, perceived responsibility to provide income, and knowledge on accessing grants. In Motherwell, perceived feelings of helplessness $(\beta=.29 ; \mathrm{SE}=.14, \mathrm{p}<.05)$, and perceived responsibility to provide income $(\beta=.23 ; \mathrm{SE}=.07, \mathrm{p}<.01)$ were positively 
associated with the perceived ability to provide income. In Uitenhage no significant associations were found for both concepts $(\beta=-.13 ; \mathrm{SE}=.08 ; \mathrm{p}>.05$ and $\beta=.01 ; \mathrm{SE}$ $=.05 ; \mathrm{p}>.05)$. In Uitenhage, attitude towards people living with HIV and AIDS was negatively related to perceived ability to provide income $(\beta=-.29 ; \mathrm{SE}=.06, \mathrm{p}<$ $.001)$, which was not found in Motherwell $(\beta=.09 ; \mathrm{SE}=.09 ; \mathrm{p}>.05)$. Finally, in Motherwell, knowledge about accessing grants was negatively associated with perceived ability to provide income $(\beta=-.08 ; \mathrm{SE}=.03, \mathrm{p}<.05)$, while in Uitenhage the association was positive $(\beta=.06 ; \mathrm{SE}=.03, \mathrm{p}<.05)$. Forty-one percent of the variance in perceived ability to provide income could be explained by the correlates in the model.

\section{Perceived ability to relax}

Attitude towards communication, perceived responsibility to provide income, perceived behaviour control over providing nursing care, attitude towards relaxation, subjective norm towards providing care, and knowledge on accessing grants uniquely contributed to the prediction of perceived ability to relax. In addition, interaction effects were found between site and, respectively, attitude towards communication, perceived responsibility to provide income, perceived behaviour control over providing nursing care, and knowledge on accessing grants. In both Motherwell ( $\beta=$ $.12 ; \mathrm{SE}=.09, \mathrm{p}>.05)$ and Uitenhage $(\beta=-.20 ; \mathrm{SE}=.10, \mathrm{p}>.05)$, attitude towards communication was not significantly related to perceived ability to relax. In Uitenhage, both perceived behaviour control over providing nursing care $(\beta=.16$; SE $=.05, \mathrm{p}<.001)$ and knowledge on accessing grants $(\beta=.15 ; \mathrm{SE}=.03, \mathrm{p}<.001)$ were positively associated with perceived ability to relax; whereas attitude towards providing income was negatively related to perceived ability to relax $(\beta=-.22 ; \mathrm{SE}=$ $.07, \mathrm{p}<.001)$. In Motherwell, no significant associations were found between 
perceived behaviour control over providing nursing care $(\beta=.00 ; \mathrm{SE}=.04, \mathrm{p}>.05)$, knowledge on accessing grants $(\beta=.03 ; \mathrm{SE}=.03, \mathrm{p}>.05)$, attitude towards providing income $(\beta=.05 ; \mathrm{SE}=.06, \mathrm{p}>.05)$ and perceived ability to relax. The total model accounted for $37 \%$ of the variance in perceived ability to relax.

\section{Discussion}

In the present study, theoretical psychosocial constructs such as attitudes, perceived behaviour control over providing nursing care, personal and subjective norms towards providing care and knowledge on accessing grants were important predictors across the four ability dimensions. In addition, different correlates emerged for the different dimensions of caring ability that were explored. The most important predictors of caregivers' perceived ability to provide nursing care were more knowledge on accessing grants and a more positive personal norm towards providing care. Perceived ability to communicate effectively with children and grandchildren was predicted most strongly by a more positive attitude towards communication. A more negative attitude towards people living with HIV or AIDS and a more positive attitude towards communication were the primary predictors for perceived ability to provide income. Only in Motherwell feelings of helplessness were positively associated with perceived ability to provide income. The main predictors of perceived ability to relax were a more negative attitude towards communication, lower perceived responsibility to provide income and a higher perceived behaviour control over providing nursing care.

Somewhat counterintuitive was the finding that a more negative attitude towards people living with HIV or AIDS contributed to a higher perceived ability to provide income. This finding could possibly be explained by the impact that interpersonal or environmental variables have on the ability to provide income. 
Factors such as for example a bad relationship between the sick person and the caregiver, the reason why the older person took on the care-giving role (Nyambedha, Wandibba, \& Aagaard-Hansen, 2003) or fear of disclosure and stigma from the community (Moore, 2008; Mwinituo \& Mill, 2006) could have possibly contributed to a more negative attitude towards people living with HIV or AIDS. However these factors might not be restricting an older person's ability to provide income, especially when support from family or community members (Orner, 2006) is available. A negative attitude towards people living with HIV and AIDS could on the other hand also lead to social exclusion of the person infected with HIV as well as the family caregiver (Mwinituo \& Mill, 2006), resulting in less support from the community. The counterintuitive finding that a more negative attitude towards communication and a more negative attitude towards providing income contributed to higher perceived ability to relax could possibly be explained by older people not perceiving themselves responsible to provide income and to communicate effectively with children and grandchildren and therefore allow themselves time to relax.

Overall, by determining the relative importance of social cognitive constructs in understanding care-giving related behaviours these findings add relevant information to existing research that mostly used qualitative study designs to determine the needs, consequences and challenges of older caregivers (e.g. Boon et al., 2009a; Schatz \& Ogunmefun, 2007; Ssengonzi, 2007; Ssengonzi, 2008; Williams \& Tumwekwase, 2001). Nevertheless one should be cautious in generalising the findings to other populations as this study was conducted among a convenience sample of older people in the Eastern Cape of South Africa. More case studies are needed to confirm our findings and extend the current knowledge base of psychosocial correlates of the ability to provide home care in the context of HIV and 
AIDS. Furthermore, the differences in findings we found between demographically comparable sites emphasise the importance of a detailed needs assessment and analysis of important predictors of outcome variables for every new study context. In addition to differences between sites, differences might also be found within sites among subpopulations, for example when comparing grandparents caring for only grandchildren versus grandparents caring for both adult and grandchildren.

To conclude, this study has improved the understanding of the most important variables impacting on the care-giving ability of older people in the context of HIV and AIDS. By providing a core list of possible intervention targets (e.g. attitudes, personal norms towards providing care, perceived behaviour control over providing nursing control and knowledge on accessing grants) it provides valuable information for the systematic design and evaluation of educational interventions to assist older people in coping with their care-giving concerns. 


\section{References}

Boon, H., James, S., Ruiter, R.A.C., Van den Borne, B., Williams, E., \& Reddy, P. (2009a; under review). Challenges for older caregivers in a time of HIV and AIDS: A qualitative analysis.

Boon, H., Ruiter, R.A.C., James, S., Van den Borne, B., Williams, E., \& Reddy, P. (2009b; under review). Correlates of grief among older people caring for children and grandchildren as a result of HIV and AIDS in South Africa.

Chazan, M. (2008). Seven 'deadly' assumptions: Unravelling the implications of HIV/AIDS among grandmothers in South Africa and beyond. Ageing \& Society, 28, 935-958.

Clark, S.J., Collinson, M.A., Kahn, K., Drullinger, K., \& Tollman, S.M. (2007). Returning home to die: Circular labour migration and mortality in South Africa. Scandinavian Journal of Public Health, 35 (S69), 35-44.

Connor, M. \& Norman, P. (2005). Predicting health behaviour: A social cognition approach. In: Predicting health behaviour: Research and practice with social cognition models. M. Connor and P. Norman (Eds.). Berkshire, UK: Open University Press

Department of Health, South Africa (2007). National HIV and Syphillis Antenatal Sero-Prevalence Survey in South Africa 2006. Directorate Health Systems Research, Research Coordination \& Epidemiology.

Department of Provincial and Local Government South Africa (2008). Economic snapshot: Motherwell, Eastern Cape. Available online at: http://www.thedplg.gov.za/urp/index2.php?option=com_docman\&task=doc_view $\underline{\text { \&gid }=87 \& \text { Itemid }=54}[03.11 .2008]$ 
Development Partners (2007). Nelson Mandela Bay Municipality - Demographic Update and Socio-Economic Analysis / Quality of Life in 26 'Change Areas' 2006/7. Available online at http://www.dpart.co.za/documents/DemographicUpdateExecSummary.pdf [03.11.2008]

Freeman, M. \& Nkomo, N. (2006). Guardianship of orphans and vulnerable children. A survey of current and prospective South African caregivers. AIDS Care, 18, 302310.

Hosegood, V. \& Timaeus, I.M. (2006). HIV/AIDS and older people in South Africa. In: Aging in Sub-Saharan Africa: Recommendations for furthering research. B. Cohen and J. Menken (Eds.). Washington: The National Academies Press.

Knodel, J. (2005). Researching the impact of the AIDS epidemic on older-age parents in Africa: Lessons from studies in Thailand. Generations Review, 15, 16-22.

Madhavan, S. (2004). Fosterage patterns in the age of AIDS: continuity and change. Social Science \& Medicine, 58, 1443-1454.

Marais, H. (2005). Buckling: The impact of AIDS in South Africa. Pretoria: University of Pretoria Press.

Moore, A.R. (2008). Older poor parents who lost an adult child to AIDS in Togo, West Africa: A qualitative study. OMEGA The Journal of Death and Dying, 56, 289-302.

Mwinituo, P.P. \& Mill, J.E. (2006). Stigma associated with Ghanaian caregivers of AIDS patients. Western Journal of Nursing Research, 28, 369-382.

Nelson Mandela Bay Municipality (2008). Integrated Development Plan 2008 - 2012 of the Nelson Mandela Bay Metropolitan Municipality. Available online at 
http://www.nelsonmandelabay.gov.za/Documents.aspx?objID=85\&cmd=download $\underline{\& d o c I D=487}[03.11 .2008]$

Ntozi, J.P.M. \& Nakayiwa, S. (1999). AIDS in Uganda: How has the household coped with the epidemic? The continuing African HIV/AIDS epidemic. Canberra: Health Transition Centre, National Centre for Epidemiology and Population Health, Australian National University.

Nyambedha, E.O., Wandibba, S., \& Aagaard-Hansen, J. (2003). "Retirement lost" the new role of the elderly as caretakers for orphans in Western Kenya. Journal of Cross-Cultural Gerontology, 18, 33-52.

Orner, P. (2006). Psychosocial impacts on caregivers of people living with AIDS. AIDS Care, 18, 236-240.

Reddy, P. (2005). 'Inkala ixinge etyeni: Trapped in a difficult situation'. The burden of care on the elderly in the Eastern Cape, South Africa. Horizons Research Update. Johannesburg: Population Council

Schatz, E.J. (2007). "Taking care of my own blood": Older women's relationships to their households in rural South Africa. Scandinavian Journal of Public Health, 35 (S69), 147-154.

Schatz, E. \& Ogunmefun, C. (2007). Caring and contributing: The role of older women in rural South African multi-generational households in the HIV/AIDS era. World Development, 35, 1390-1403.

Ssengonzi, R. (2007). The plight of older persons as caregivers to people infected/affected by HIV/AIDS: Evidence from Uganda. Journal of Cross-Cultural Gerontology, 22, 19-42.

Ssengonzi, R. (2008). The impact of HIV/AIDS on the living arrangements and wellbeing of elderly caregivers in rural Uganda. AIDS Care, in press, 1-6. 
Statistics South Africa (2007). Community survey 2007. Municipal data on household services. Pretoria: Statistics South Africa.

Williams, A. \& Tumwekwase, G. (2001). Multiple impacts of the HIV/AIDS epidemic on the aged in rural Uganda. Journal of Cross-Cultural Gerontology, 16, $221-236$. 
Table 1: Overview of scale measures

\begin{tabular}{|c|c|c|c|c|}
\hline Measure & Example & Scale & $\begin{array}{l}\text { Number } \\
\text { of items }\end{array}$ & $\begin{array}{l}\text { Cronbach' } \\
\text { s alpha }(\alpha)\end{array}$ \\
\hline $\begin{array}{l}\text { 1. Perceived ability to } \\
\text { provide nursing care }\end{array}$ & $\begin{array}{l}\text { I am able to... } \\
\text { - get my sick child out of bed } \\
\text { - make sure my sick child takes his/her } \\
\text { medication in time }\end{array}$ & $\begin{array}{l}1=\text { Definitely no } \\
2=\text { No } \\
3=\text { I don't know } \\
4=\text { Yes } \\
5=\text { Definitely yes }\end{array}$ & 8 & .91 \\
\hline $\begin{array}{l}\text { 2. Perceived ability to } \\
\text { communicate } \\
\text { effectively with } \\
\text { dependents }\end{array}$ & $\begin{array}{l}\text { I am able to... } \\
\text { - listen to what my children have to say } \\
\text { - ask my children about their daily } \\
\text { activities }\end{array}$ & $\begin{array}{l}1=\text { Definitely no } \\
2=\text { No } \\
3=\text { I don't know } \\
4=\text { Yes } \\
5=\text { Definitely yes }\end{array}$ & 7 & .78 \\
\hline $\begin{array}{l}\text { 3. Perceived ability to } \\
\text { provide income }\end{array}$ & $\begin{array}{l}\text { I am able to... } \\
\text { - meet the financial commitments of the } \\
\text { family } \\
\text { - apply for a grant for my child or } \\
\text { grandchild }\end{array}$ & $\begin{array}{l}1=\text { Definitely no } \\
2=\text { No } \\
3=\text { I don't know } \\
4=\text { Yes } \\
5=\text { Definitely yes }\end{array}$ & 8 & .81 \\
\hline $\begin{array}{l}\text { 4. Perceived ability to } \\
\text { relax }\end{array}$ & $\begin{array}{l}\text { I am able to... } \\
\text { - sit down and do something for myself } \\
\text { - talk to someone about my worries }\end{array}$ & $\begin{array}{l}1=\text { Definitely no } \\
2=\text { No } \\
3=\text { I don't know } \\
4=\text { Yes } \\
5=\text { Definitely yes }\end{array}$ & 6 & .80 \\
\hline $\begin{array}{l}\text { 5. Perceived care } \\
\text { burden* }\end{array}$ & $\begin{array}{l}\text { Do you have to... } \\
\text { - give your child a bath or a wash? } \\
\text { - help your grandchild or other children } \\
\text { with their homework? } \\
\text { If yes, how much of a burden is this for } \\
\text { you? }\end{array}$ & $\begin{array}{l}1=\text { no burden at all } \\
2=\text { not so much of a burden } \\
3=\text { a heavy burden }\end{array}$ & 29 & .97 \\
\hline $\begin{array}{l}\text { 6. Perceived } \\
\text { behaviour control over } \\
\text { daily care activities }\end{array}$ & $\begin{array}{l}\text { How easy or difficult do you find it to... } \\
\text { - cheer up your child when he/she is feeling } \\
\text { sad? } \\
\text { - provide enough food for your family? }\end{array}$ & $\begin{array}{l}1=\text { difficult } \\
2=\text { not so easy } \\
3=\text { easy }\end{array}$ & 6 & .80 \\
\hline $\begin{array}{l}\text { 7. Perceived feelings } \\
\text { of helplessness }\end{array}$ & $\begin{array}{l}\text { How often do you feel helpless when... } \\
\text { - your child is feeling sad? } \\
\text { - you want to help your child solve his/her } \\
\text { problems? }\end{array}$ & $\begin{array}{l}1=\text { never } \\
2=\text { sometimes } \\
3=\text { often }\end{array}$ & 6 & .73 \\
\hline 8. Self care & $\begin{array}{l}\text { How often do you... } \\
\text { - talk about your care-giving difficulties to } \\
\text { other elderly parents who are also caring } \\
\text { for children or grandchildren } \\
\text { - manage to relax yourself }\end{array}$ & $\begin{array}{l}1=\text { never } \\
2=\text { sometimes } \\
3=\text { often }\end{array}$ & 3 & .62 \\
\hline $\begin{array}{l}\text { 9. Attitude towards } \\
\text { people living with } \\
\text { HIV or AIDS }\end{array}$ & $\begin{array}{l}\text { - Would you use the same toilet as } \\
\text { someone who is infected with HIV? } \\
\text { - If you knew the person who is selling } \\
\text { food is infected with HIV, would you buy } \\
\text { food from him/her }\end{array}$ & $\begin{array}{l}1=\text { definitely no } \\
2=\text { no } \\
3=\text { I don't know } \\
4=\text { yes } \\
5=\text { definitely yes }\end{array}$ & 6 & .69 \\
\hline $\begin{array}{l}\text { 10. Attitude towards } \\
\text { communication }\end{array}$ & $\begin{array}{l}\text { How important is it for you to... } \\
\text { - listen to what your children have to say? } \\
\text { - talk to your children in a language they } \\
\text { understand? }\end{array}$ & $\begin{array}{l}1=\text { not important at all } \\
2=\text { not important } \\
3=\text { I don't know } \\
4=\text { important } \\
5=\text { very important }\end{array}$ & 8 & .78 \\
\hline 11. Perceived & I feel that it is easy to... & $1=$ strongly disagree & 6 & .93 \\
\hline
\end{tabular}




\begin{tabular}{|c|c|c|c|c|}
\hline $\begin{array}{l}\text { behaviour control over } \\
\text { providing nursing care }\end{array}$ & $\begin{array}{l}\text { - bath my sick child } \\
\text { - give my sick child medications every day }\end{array}$ & $\begin{array}{l}2=\text { disagree } \\
3=\text { neither agree }, \text { nor disagree } \\
4=\text { agree } \\
5=\text { strongly agree }\end{array}$ & & \\
\hline $\begin{array}{l}\text { 12. Perceived } \\
\text { responsibility to } \\
\text { provide income }\end{array}$ & $\begin{array}{l}\text { - It is my responsibility that all household } \\
\text { members can eat } \\
\text { - It is my responsibility to apply for my } \\
\text { child's grant }\end{array}$ & $\begin{array}{l}1=\text { strongly disagree } \\
2=\text { disagree } \\
3=\text { neither agree }, \text { nor disagree } \\
4=\text { agree } \\
5=\text { strongly agree }\end{array}$ & 5 & .84 \\
\hline $\begin{array}{l}\text { 13. Attitude towards } \\
\text { relaxation }\end{array}$ & $\begin{array}{l}\text { - Relaxing is an essential part of care- } \\
\text { giving } \\
\text { - I deserve to take time for myself }\end{array}$ & $\begin{array}{l}1=\text { strongly disagree } \\
2=\text { disagree } \\
3=\text { neither agree }, \text { nor disagree } \\
4=\text { agree } \\
5=\text { strongly agree }\end{array}$ & 4 & .93 \\
\hline $\begin{array}{l}\text { 14. Personal norm } \\
\text { towards providing } \\
\text { care }\end{array}$ & $\begin{array}{l}\text { I feel it's my moral duty to... } \\
\text { - provide the family with a meal every day } \\
\text { - make sure my child or grandchild is } \\
\text { happy }\end{array}$ & $\begin{array}{l}1=\text { strongly disagree } \\
2=\text { disagree } \\
3=\text { neither agree }, \text { nor disagree } \\
4=\text { agree } \\
5=\text { strongly agree }\end{array}$ & 5 & .95 \\
\hline \multirow[t]{2}{*}{$\begin{array}{l}\text { 15. Subjective norm } \\
\text { towards providing } \\
\text { care* }\end{array}$} & $\begin{array}{l}\text { Perceived expectations of others: } \\
\text { Do the people around you such as family } \\
\text { members and friends expect you to... } \\
\text { - tell your children about HIV and AIDS? } \\
\text { - provide nursing care to your sick child? }\end{array}$ & $\begin{array}{l}-2=\text { definitely no } \\
-1=\text { no } \\
0=\text { I don't know } \\
1=\text { yes } \\
2=\text { definitely yes }\end{array}$ & 8 & .87 \\
\hline & $\begin{array}{l}\text { Motivation to comply to: } \\
\text { - your children } \\
\text { - your grandchildren }\end{array}$ & $\begin{array}{l}1=\text { not important at all } \\
2=\text { not important } \\
3=\text { I don't know } \\
4=\text { important } \\
5=\text { very important }\end{array}$ & 7 & .76 \\
\hline $\begin{array}{l}\text { 16. Knowledge on } \\
\text { HIV and AIDS }\end{array}$ & $\begin{array}{l}\text { - A healthy looking person can be infected } \\
\text { with HIV } \\
\text { - HIV can be prevented by an injection or } \\
\text { pill for family planning }\end{array}$ & $\begin{array}{l}1=\text { correct } \\
0=\text { incorrect }\end{array}$ & 10 & \\
\hline $\begin{array}{l}\text { 17. Knowledge on } \\
\text { accessing grants }\end{array}$ & $\begin{array}{l}\text { - A woman can apply for a state pension } \\
\text { when she is } 65 \text {, a man when he is } 60 \\
\text { - It is possible to apply for a grant-in-aid in } \\
\text { addition to an old age pension }\end{array}$ & $\begin{array}{l}1=\text { correct } \\
0=\text { incorrect }\end{array}$ & 6 & \\
\hline
\end{tabular}


Table 2: Bivariate correlations between study variables $(\mathrm{N}=401)$

\begin{tabular}{|c|c|c|c|c|c|c|c|c|c|c|c|c|c|c|c|c|c|c|}
\hline & & 1 & 2 & 3 & 4 & 5 & 6 & 7 & 8 & 9 & 10 & 11 & 12 & 13 & 14 & 15 & 16 & 17 \\
\hline 1 & Perceived ability to provide nursing care & - & & & & & & & & & & & & & & & & \\
\hline 2 & $\begin{array}{l}\text { Perceived ability to communicate } \\
\text { effectively with dependents }\end{array}$ & $.57^{\star \star \star}$ & - & & & & & & & & & & & & & & & \\
\hline 3 & Perceived ability to provide income & $.55^{\star \star \star}$ & $.50^{\star \star \star}$ & - & & & & & & & & & & & & & & \\
\hline 4 & Perceived ability to relax & $.56^{\star \star *}$ & $.56^{* * *}$ & $.57^{* \star *}$ & - & & & & & & & & & & & & & \\
\hline 5 & Perceived care burden & $.11^{*}$ & $-.12^{\star}$ & $.12^{*}$ & -.09 & - & & & & & & & & & & & & \\
\hline 6 & $\begin{array}{l}\text { Perceived behaviour control over } \\
\text { daily care activities }\end{array}$ & $.15^{\star \star}$ & $.18^{\star \star \star}$ & .08 & $.22^{\star \star \star}$ & $-.20^{* * *}$ & - & & & & & & & & & & & \\
\hline 7 & Perceived feelings of helplessness & -.01 & $-.19^{\star \star *}$ & $-.13^{*}$ & .02 & .04 & $.17^{\star \star *}$ & - & & & & & & & & & & \\
\hline 8 & Self-care & .08 & .05 & $.12^{*}$ & .06 & .07 & .10 & .02 & - & & & & & & & & & \\
\hline 9 & $\begin{array}{l}\text { Attitude towards people living with HIV } \\
\text { or AIDS }\end{array}$ & $.39^{\star \star \star}$ & $.46^{\star \star \star}$ & $.26^{* \star \star}$ & $.34^{\star \star \star}$ & -.07 & $.10^{*}$ & $-.18^{\star * *}$ & .09 & - & & & & & & & & \\
\hline 10 & Attitude towards communication & $.39^{\star \star *}$ & $.60^{\star \star \star}$ & $.39^{\star \star \star}$ & $.33^{\star \star \star}$ & -.06 & $.13^{* *}$ & $-.24^{\star * *}$ & -.01 & $.34^{\star \star \star}$ & - & & & & & & & \\
\hline 11 & $\begin{array}{l}\text { Perceived behaviour control over } \\
\text { providing } \\
\text { nursing care }\end{array}$ & $.45^{\star \star \star}$ & $.37^{\star \star \star}$ & $.38^{\star \star \star}$ & $.40^{\star \star \star}$ & .08 & .06 & -.02 & -.02 & $.12^{*}$ & $.28^{\star \star \star}$ & - & & & & & & \\
\hline 12 & $\begin{array}{l}\text { Perceived responsibility } \\
\text { to provide income }\end{array}$ & $.29^{\star \star \star}$ & $.28^{* \star *}$ & $.48^{\star * *}$ & $.32^{* * \star}$ & .01 & -.03 & $-.19^{\star \star \star}$ & $-.14^{* *}$ & $.14^{* *}$ & $.35^{\star * *}$ & $.59^{* * *}$ & - & & & & & \\
\hline 13 & Attitude towards relaxation & -.06 & -.03 & $.26^{\star \star \star}$ & $.17^{* \star \star}$ & .03 & $-.14^{\star *}$ & $-.15^{\star \star}$ & .02 & .05 & -.02 & $.19^{\star \star \star}$ & $.36^{\star * \star}$ & - & & & & \\
\hline 14 & Personal norm towards providing care & $.28^{\star \star \star}$ & $.22^{* * *}$ & $.40^{* * *}$ & $.25^{* * *}$ & .08 & -.06 & $-.11^{*}$ & -.02 & $.12^{*}$ & $.27^{\star \star *}$ & $.43^{\star * \star}$ & $.59^{\star \star *}$ & $.22^{* \star *}$ & - & & & \\
\hline 15 & Subjective norm towards providing care & $.55^{\star \star \star}$ & $.57^{* * *}$ & $.56^{* \star *}$ & $.60^{* * *}$ & -.01 & $.18^{* \star *}$ & $-.11^{*}$ & .10 & $.49^{* * *}$ & $.42^{\star * *}$ & $.22^{* * *}$ & $.25^{* * *}$ & $.11^{*}$ & $.26^{* * *}$ & - & & \\
\hline 16 & Knowledge on HIV and AIDS & $.26^{\star \star \star}$ & $.35^{\star \star *}$ & $.25^{\star \star \star}$ & $.29^{\star \star \star}$ & $-.10^{\star}$ & $.22^{\star \star \star}$ & -.05 & .09 & $.37^{* \star \star}$ & $.32^{\star \star \star}$ & .00 & .09 & .02 & $.10^{*}$ & $.42^{\star \star \star}$ & - & \\
\hline 17 & Knowledge on accessing grants & $.31^{* \star *}$ & $.23^{* \star *}$ & $.17^{\star \star \star}$ & $.27^{\star \star \star}$ & $.20^{\star \star \star}$ & .09 & -.04 & $.14^{* \star}$ & $.24^{\star \star \star}$ & $.13^{* *}$ & $.22^{\star * \star}$ & .01 & $-.12^{\star}$ & .05 & $.19^{* \star *}$ & $.13^{* *}$ & - \\
\hline & Mean & 3,94 & 4,11 & 3,67 & 3,93 & 2,07 & 1,76 & 1,73 & 3,88 & 4,47 & 3,61 & 4,03 & 3,90 & 4,39 & 4,18 & 2,14 & 3.61 & 2.92 \\
\hline & Standard deviation & 0,82 & 0,53 & 0,70 & 0,66 & 0,29 & 0,53 & 0,38 & 0,53 & 0,40 & 1,03 & 0,76 & 0,92 & 2,88 & 0,85 & 0,38 & 2.81 & 1.17 \\
\hline & Minimum & 1 & 1 & 1 & 1 & 1 & 1 & 1 & 1 & 1 & 1 & 1 & 1 & -10 & 1 & 1 & 0 & 0 \\
\hline & Maximum & 5 & 5 & 5 & 5 & 3 & 3 & 3 & 5 & 5 & 5 & 5 & 5 & 10 & 5 & 3 & 10 & 6 \\
\hline
\end{tabular}

$* \mathrm{p}<.05 \quad * * \mathrm{p}<.01 \quad * * * \mathrm{p}<.001$ 
Table 3: Estimates of fixed effects for the ability to provide care, communicate, provide income and relax (controlled for random effect of interviewer)

\begin{tabular}{|c|c|c|c|c|}
\hline Perceived ability to: & Provide nursing care & $\begin{array}{c}\text { Communicate effectively with } \\
\text { dependents }\end{array}$ & Provide income & Relax \\
\hline & Beta (SE) & Beta (SE) & Beta (SE) & Beta (SE) \\
\hline Intercept & $3.96(.14)$ & $4.14(.07)$ & $3.66(.13)$ & $3.91(.11)$ \\
\hline Study site & $-.10(.19)$ & $-.10(.10)$ & $-.05(.18)$ & $.01(.16)$ \\
\hline Perceived care burden & $.11(.04)^{* *}$ & $-.02(.03)$ & $.05(.03)$ & \\
\hline Perceived behaviour control over daily care activities & $-.03(.06)$ & $-.02(.04)$ & & $-.02(.05)$ \\
\hline Perceived feelings of helplessness & & $-.04(.06)$ & $-.13(.09)$ & \\
\hline Interaction with study site & & & $.44(.16)^{* *}$ & \\
\hline Attitude towards people living with HIV or AIDS & $.13(.06)^{*}$ & $.10(.04)^{*}$ & $-.31(.07)^{* * *}$ & $-.08(.05)$ \\
\hline Interaction with study site & & & $.43(.10)^{* * *}$ & \\
\hline Attitude towards communication & $-.04(.08)$ & $.32(.05)^{* * *}$ & $.16(.07)^{*}$ & $-.20(.09)^{*}$ \\
\hline Interaction with study site & & & & $.32(.13)^{*}$ \\
\hline Perceived behaviour control over providing nursing care & $.01(.05)$ & $.07(.03)^{* *}$ & $.02(.03)$ & $.17(.05)^{* * *}$ \\
\hline Interaction with study site & $.21(.06)^{* *}$ & & & $-17(.06)^{* *}$ \\
\hline Perceived responsibility to provide income & $-.02(.05)$ & $-.02(.03)$ & $.01(.05)$ & $-.19(.06)^{* * *}$ \\
\hline Interaction with study site & & & $.21(.07)^{* *}$ & $.21(.08)^{*}$ \\
\hline Attitude towards relaxation & & & $.02(.03)$ & $.13(.03) * * *$ \\
\hline Personal norm towards providing care & $.18(.04)^{* * *}$ & $.00(.02)$ & $.06(.03)^{*}$ & $.05(.03)$ \\
\hline Interaction with study site & $-.27(.08)^{* * *}$ & & & \\
\hline Subjective norm towards providing care & $.07(.01)^{* * *}$ & $.03(.01)^{* * *}$ & $.06(.01)^{* * *}$ & $.05(.01)^{* * *}$ \\
\hline Knowledge on HIV and AIDS & $.00(.01)$ & $.01(.01)$ & $.01(.01)$ & $.01(.01)$ \\
\hline Knowledge on accessing grants & $.20(.04)^{* * *}$ & $.06(.02)^{*}$ & $.06(.03)^{*}$ & $.14(.03) * * *$ \\
\hline Interaction with study site & $-.24(.05)^{* * *}$ & $-.08(.03)^{*}$ & $-.14(.04)^{* * *}$ & $-.10(.04)^{*}$ \\
\hline $\mathrm{R}^{2}$ & .41 & .49 & .41 & .37 \\
\hline
\end{tabular}

